\title{
Assessing Relationship AmongManagerial Ownership, Leverage and Dividend Policy: Evidence From Pakistani Listed Firms in PSX 100 Index
}

\author{
Dr. IHTESHAM KHAN \\ Assistant Professor, Institute of Business Studies and Leadership \\ Abdul Wali Khan University, Mardan \\ Email: ihtishamkhan@awkum.edu.pk \\ Dr. SHAH RAZA KHAN \\ National Bank of Pakistan. \\ Email:shah.raza@nbp.com.pk
}

\author{
ADNAN KHATTAK \\ MBA, Scholar, Institute of Business Studies and Leadership \\ Abdul Wali Khan University, Mardan. \\ Email: adnankhattak.84@gmail.com
}

\begin{abstract}
The aim of this study is to investigate the relationship between the managerial ownership, leverage and dividend Payout. The analysis is performed using GMM estimation on a sample of 40 non-financial listed Firms of Pakistan stock exchange for the period 2010-2016. The results show that there is negative association between Managerial ownership and Leverage, Positive association between Managerial ownership and Dividend payout. Leverage and Dividend payout has negative association. However, conflicting to expectations, managerial ownership is found to have positive impact on dividend. It means that companies with higher levels of managerial holdings are consciously choosing higher level of dividends.
\end{abstract}

Keywords: Managerial Ownership, Leverage and Dividend Policy.

\section{Introduction}

Mostly in organizations it is stated that the common performance of the manager is to increase and boost the wealth of the organization shareholder's but it is seemed in organization that those managers who didn't have any share portion or did not have any ownership then the decision of the manger will not good for shareholders because they don't have any kind of risk in that decision. So such kind of conflict between the mangers and shareholder's lead to Agency conflict problem and increase the level of cost (Jensen \& Meckling, 1976).

For the development of a country economy and improvement in standard of living growth is needed. Many of the studies provide different evidence related to the growth and development of economy through which the economic goal can be easily achieved. In business field the competitions between different organizations are increasing day by day every organization is struggling to stay in competition and survive with strong competitive position. For this reason it is very important that corporation implement good 
strategies and planning and also needed to manage resources optimally among the bundle of resources one of them is the capital and capital structure. It means that how the organization uses the capital and debt to get high return in the market. The capital structure is one of the most difficult and risky decision for organization because there is high risk involve with it, If the combination work it give high return but in the situation of failure the result is opposite (Abor, 2005). In success and high performance of the organization the capital structure playing a significant role the optimal structure of capital give and maximizing the return of the organization which give extra edge for firm in the rivalry market of different organization. Risk charming is predictable for managers in order to shun key pressure to the organization (Jensen \&Meckling, 1976).

Corporate governance is one of the most attractive and good side of business because good corporate governance adds a supportable outcome in the development of economies by attractive performance of firms and also making organization able to increase the finance from outside capital market. The structure of corporate ownership plays a vital role in the motivation and reducing the agency conflict and cost because it works like the instrument and in the corporation the agency cost effect on the profitability of the organization. It directly declines the position of corporation, this cost is associated with the corporation ownership and the selected board of management can be used to shield property rights of the organization (Berle\& Means, 1932).

In the global market good corporate governance has some good policies and objectives to adopt strategy for it, Good corporate governance reduces and avoid different problems of organization and also trying to create association between management, CEO, board of directors and shareholders (Majority shareholders and minority shareholders). In Pakistan, the CG codes are made in 2002 that help corporation at high level. In corporate governance different Practices and regulation are comprised such as standard of accounting, law concerning financial disclosure as related to firms, the executive compensations and remunerations, the size and combination of board etc. The perception of corporate governance assumes an important pressure between shareholders and corporate managers (Berle\& Means, 1932: Jensen \&Meckling, 1976).

Corporate governance can be distinct in numerous parts though we are clever to categorize it into two main classes, One set of concepts shacks light on practical trends of practical matters and assessment of performance e.g. Debt Equity Mix, efficiency, performance, and association to the company stockholders and other stakeholders. Chitchat about the next class it comprehends some normative concepts and they are approximately the guidelines and principles and ethics issued by investigators, capital markets, bench and labor marketplaces.

The current situation shows that each and every business has significantly affection from corporate governance practices throughout the world. It is experienced from the past events which strike the role and regulation of corporate governance. In 1997 after the financial crises of Asian market and the scandal of ENRON Company in 2003, the scandal of Marten Stewart in 2004 etc., all of these Crises and scandals highlight the important and vital role of corporate governance (Vishwa \& Maruya, 2015).

\section{Problem Statement}

Many researchers argue that a significant relationship exist among managerial ownership, dividend and leverage financing. (VO \& Nguyen, 2014). Prior empirical studies have been conducted to mainly investigate there problem independently with each other in the context of Pakistan stock exchange. In light of the direct relationships among these policies, empirical studies on this topic are limited in the Pakistani context. So, this paper empirically analyzes the relationship among a firm's managerial ownership, leverage and dividend policies. 


\section{Research Question}

To find out the relationship among Managerial ownership, Leverage and Dividend policy in context of Pakistani Firms?

\section{Hypothesis of the study}

H1: The effect of Managerial ownership and Leverage on Dividend policy.

$\mathrm{H} 2$ : The effect of Leverage and dividend policy on managerial ownership.

H3: The effect of Dividend policy and managerial ownership on leverage.

\section{Literature Review}

The concept of corporate governance is not the new phenomenon in the organization but it is noticed in different crises and failure of organization. The importance of the corporate governance is increased more from past days. In the current increasing competition and increasing margin of profit, the corporate governance plays a main role in it. Numerous of the explanations and definitions stated many of the researchers, investigators and the scholars but all of them mostly concentrated on the issued and difficulties that happening due to management or organization and board of directors, the direction of a corporation and the association between top level organizations and to the diverse stakeholders (Ruppen, 2008). Good corporate governance practices make sure the effective distribution and allocation of organization resources (Chepkwony, 2015).

Wescott(2000) argues that the corporate governance creates and establishes rules and regulation, codes creating structures and procedures, also controlling techniques for the management of firms. The main goal of Corporate Governance is to protect the stakeholders benefit. Nielsen (2000) suggests that the Problem of Agency and for the reduction of cost of organization will be reducing through the corporate governance, because it is like an instrument for reduction of these problems. Manager incurred different other type of cost for their own benefit because manager is trying to increase and work for their own benefits instead of working for shareholders and owner benefits (Kidd \& Richter, 2003).

Corporate governance is the system of balancing and checking of different resources. The objective of corporate governance is to monitor and controlling the activities of management in organization (Solomon $\&$ Solomon, 2004). How different resources responsibilities and rights among different workforce are equally and efficiently be distributed, and it will be done through the corporate governance. Corporate governance creates different codes and provide different explanation, techniques and regulation that how should a good and accurate decision (Clarke, 2004).

The issue related to Boards and its structure is highly highlighted by different researchers and also different media cells and also gets a high attention from different aspects from couple of decades. A work which is conducted by the Lipton and Lorch (1992) and Jensen (1993) on the Board and on its size, they state from research that the success of a company is depend on the vital role and efficiency of board, because it works as intermediaries between the investors and the managers (Mallin, 2004).

The combination of different directors known as the size of boards is different from country to country, firm to firm due to its different culture, different type of rules and regulation and also the type of ownership structure. Many of the scholars adopt and present different kind of theories that how should be built a board that should be accurate and efficient as beyond the expectation. Due to this reasons board variety has been commonly deliberated between organizations and researchers for an extensive time. (Millikem, \& Martins, 1996) investigate that a board is the combination and mixture of different member in form of human capital where each and everyone have different kind of skills, abilities, knowledge and expertise which they get from different experiences and education. 
The structure of boards is set the team for managing and creating competitive situation of organization. In case the number of members is more than there is a huge problem of agency theory is arising because most of the directors trying to work for his own benefit (Boone et al., 2007). Small size of board directors has more responsible of the organization and taking more responsibility of organization in form of monitoring the operation good than the large in number board of directors (Vaefas, 2000).

As per the study of Macit (2011), they used the ROA and ROE factors to determine the profitability of firm, and also focused to evaluate specific factors which are conducted on the turkey firms, this work just focused on the firm specific factors for the determination of firm profitability, from the study is derived that NPL to TA has significant impact on the profitability.

According to the study result of Eisenbeis et al. (1999) examined the US firms' profitability by using the method of different techniques, they conclude from this work that both of the techniques give very useful Profitability information, and also it indicates for the management who have the control of taking decision that place and use more weight in the method of SFA estimation. Chu and Lim (1998) use the DEA method for the Singapore firming study. The Sufian and Majid (2006) also implement the DEA technique for the listed firms of the Malaysian for the period of 2002-2003. Pasiouras et al. (2007) conduct study on 10 Greece firms, they examined the ASE listed firms, the result show that there is positive association between the changes and the Profitability, and also find out that there also effect on the return of stock. But on the other aspect that changing in Profitability have no effect on the return of stock price (Hongmei Gu \& Jiahui Yue, 2011).

As related to market is noticed that the structures of market also effecting the profitability because it seemed that whenever the ration value is higher this will increase the profitability. A dynamic situation is in the market for which every organization are struggling the situation where the firm has high level of market and has a differentiate product and services, the organization can get more return, power and create a monopolistic situation where all of the profits received one person.

Firm growth is the important aspect of the organization development. The firm profitability and growth is very important for organization, different investigative research works are conducted on it to know about the important and impact of the firm growth. All of the previous studies are trace back to the theory of the firm growth almost the entire investigator uses in his or her studies this theory. The Viner (2008) investigate that the growth theory is based on the U-shaped long run cost task, fixed cost is one of the portions of the organization whole cost which is considered that it may not be reduced, but it will be reduced in case of when the organization increase production level in the same period. In contrast of this the average cost of the organization can be decrease through the $\mathrm{U}$-shaped long run cost function this like condition considered as the Economies of the scale situations. It will initiate with fixed cost and it will increase the production capacity of the organization by reducing per unit cost. It is noticed that whenever the organization first time achieve a positive design capacity then they experience that how to increase the production, and how to reduce per unit cost to boost the production. After the achievement, such design capacity then organization situation become unchangeable scale but there is another situation is occurring whenever the organization size is raised more than the "economies of scale change to diseconomies of scale". This will happen due to an increase of the management cost like the cost of Communication and the bureaucratization. That's why average cost of the organization goes up and the curve of this recommends that those organizations that have small size are more opportunities of growth as compare to large size of organization. These low opportunities for large organization happen due to diseconomies of scale (jolgan, 2005).

\section{Methodology}

After review of an empirical study on managerial ownership, dividend policy and leverage, the study is conducted to test the hypothesis. This area is important to alleviate the agency problem and to maximize 
the shareholder profit. The leverage policy and dividend are used a substitute for managerial ownership, rising in managerial ownership lead to decrease the agency problem and the conflict between director and stakeholders (VO \&Phan, 2013).

\section{Population and Sample}

The study consists of 40 listed companies in Pakistan stock exchange during the period of 2010 to 2016. The study used the secondary data of 40 companies. This research is conducted used only secondary data, which were collected from different sources such as annual reports, company's website and financial statements of these 40 listed firms in Pakistan stock exchange.

Table 1. Definition and measurement of the variables

\begin{tabular}{|c|c|c|}
\hline Variable & Definition & Measurement \\
\hline Dependent variables & Managerial \\
ownership & $\begin{array}{c}\text { Number of shares held by directors and } \\
\text { members of the board / total outstanding } \\
\text { Shares }\end{array}$ \\
\hline LEV & Leverage & Current Liabilities + Noncurrent liabilities \\
\hline DIVR & Dividend payout & Dividend payout/ Sales \\
\hline Explanatory variables & & Current assets/ Current liabilities \\
\hline LIQ & Liquidity & (Sales - Salest-1)/ Salest-1 \\
\hline GRO & Sales growth & Earnings before tax/ Total assets \\
\hline ROA & Profitability & Tangible assets/ Total assets \\
\hline SIZE & Fixed assets & Log(total assets) \\
\hline
\end{tabular}

\section{Regression Model}

MGOit $=\alpha 0+\alpha 1$ LEVit $+\alpha 2$ DIVRit $+\alpha 3$ SGRit $+\alpha 4$ SIZE $i t+\alpha 5$ ROAit + eit $\ldots$

LEVit $=\beta 0+\beta 1$ MGOit $+\beta 2$ DIVRit $+\beta 3$ LEVDit $+\beta 4$ SIZEit $+\beta 5$ ROAit +9 it

DIVRit $=\gamma 0+\gamma 1 \mathrm{MGOit}+\gamma 2 \mathrm{LEVit}+\gamma 3 \mathrm{TANit}+\gamma 4 \mathrm{SGRit}+\gamma 5 \mathrm{ROAit}+\varepsilon i t$.

$\mathrm{MGO}=$ Managerial ownership, $\mathrm{LEV}=$ Leverage, $\mathrm{DIVP}=$ Dividend payout, $\mathrm{LEVD}=$ Liquidity

ROA $=$ Return on asset, TAN $=$ Tangible asset, Size $=$ Firm size and SGR=Sale growth

With

$\mathrm{i}=1,2, \ldots, 50$ and $\mathrm{t}=2010,2011, \ldots, 2016$

i: Number of firms

t: The estimation period

\section{Empirical Analysis}

\section{Descriptive analysis}

The descriptive analysis table 2 shows the dependent and independent variables descriptive results. The variables are taken from the study, to investigate the effect of independent variables on dependent variable. The current study is based on 40 non-financial companies listed on Pakistan Stock exchange for the period of 2010-2016, 280 observations were used in this analysis, the table contains Observations, Mean, Std. Dev. MIN, MAX, Skewness and Kurtosis value. 
Table 2: descriptive analysis of the Study Variables

\begin{tabular}{|c|c|c|c|c|c|c|c|}
\hline Variables & Obs & Mean & Std. Dev. & Min & Max & SKEWNESS & KURTOSIS \\
\hline MGO & 280 & .1493 & .269 & .0102 & 3.661 & 1.605 & 105.621 \\
\hline LEV & 280 & 1.299 & 4.478 & .0165 & 66.328 & 0.916 & 164.723 \\
\hline DPS & 280 & 1.070 & 2.867 & 0 & 22 & 1.598 & 26.935 \\
\hline LIQ & 280 & 1.381 & 1.356 & .0558 & 15.206 & 0.728 & 41.853 \\
\hline SGR & 280 & -29.295 & 154.262 & -1084.73 & 1 & -1.4578 & 31.794 \\
\hline ROA & 280 & .175 & .935 & -2.616 & 12.979 & 0.905 & 129.668 \\
\hline TANG & 280 & 1.318 & 1.944 & 0 & 14.352 & 0.981 & 22.457 \\
\hline FSIZE & 280 & 15.648 & 1.960 & 11.258 & 19.734 & -.0007 & 2.526 \\
\hline
\end{tabular}

Mean shows the average tendency of the data (Numbers). It specifies the average number of the overall data which taken in the analysis of a variable. The derived Mean for Variables are MGO 0.1493664, LEV 1.29982, DPS 1.070437, LIQ 1.381597, SGR -29.29959, ROA 0.1758937, TANG 1.318254 and FSIZE 15.64861 .

The Std. Dev. also calculated for data, Std. Dev. Calculating the differences among the observation and Mean, that how much the change is exist among the data and Mean, the calculated Std. Dev. For variables are MGO 0.2698108, LEV 4.478925, DPS 2.867026, LIQ 1.356347, SGR 154.2627, ROA 0.9355662, TANG 1.944465 and FSIZE 1.960106. The Min values show the lowest limit of the data, that how much the data is fall down. The calculated value of the MIN is: MGO 0.0102857, LEV 0.0165903, DPS 0, LIQ 0.0558773, SGR -1084.73, ROA -2.61637, TANG 0 and FSIZE 11.2586.The MAX values are calculated in the Table, the MAX shows the highest point values of the variables. MGO 3.66147, LEV 66.3289, DPS 22, LIQ 15.20631, SGR 1, ROA 12.97947, TANG 14.35213 and FSIZE 19.73481.

Skewness shows the asymmetry of the collected data distribution, which was employed in the analysis, basically, it measures the irregularity of data, how the data is scattered. To which side the variable data is scattered. To measure skewness is to measure the extent to which and also the direction in which the distribution (Curve) is non-symmetrical or skewed. The calculated Skewness for variables are: MGO 1.605241, LEV 0.91661, DPS1.598078, LIQ0.728272, SGR -1.457865, ROA0.905336, TANG0.981021 and FSIZE -0.0007887. The skewness of all variables lie between +1.96 to-1.96, which means that the data tends to be normal (Bai\& $\mathrm{Ng}, 2005$ ).

Kurtosis measure the flatness of the data, that either the data is heavy tailed or low tailed. When the data is high then it shows high tailed. Skewness and kurtosis both either show negative or positive result. It distributes to both side. The calculated value of the Kurtosis is: MGO 105.6211, LEV 164.7236, DPS 26.93513, LIQ 41.85311, SGR 31.79572, ROA 129.6687, TANG 22.45723 and FSIZE 2.526095.

\section{Correlation Analysis}

Table 3.: Correlation matrix of study Variables

\begin{tabular}{|c|c|c|c|c|c|c|c|c|}
\hline MGO & $\mathbf{L}$ & LEV & DPS & LIQ & SGR & ROA & TANG & FSIZE \\
\hline \multicolumn{9}{|c|}{$\begin{array}{ll}\text { MGO } 1.0000\end{array}$} \\
\hline \multicolumn{9}{|c|}{$-0.05781 .0000$} \\
\hline & DPS & 0.1224 & -0.0511 & \multicolumn{5}{|l|}{1.0000} \\
\hline & LIQ & 0.0248 & -0.1248 & \multicolumn{5}{|c|}{$30.1406 \quad 1.0000$} \\
\hline & SGR & -0.0572 & -0.1088 & \multicolumn{5}{|c|}{$-0.0592-0.0443 \quad 1.0000$} \\
\hline & ROA & -0.0218 & 0.6873 & \multicolumn{5}{|c|}{$\begin{array}{llll}0.0613 & 0.0751 & 0.0311 & 1.0000\end{array}$} \\
\hline & TANG & 0.0101 & 0.1024 & \multicolumn{5}{|c|}{$\begin{array}{lllll}-0.0162 & -0.0014 & -0.0719 & 0.0168 & 1.0000\end{array}$} \\
\hline & FSIZE & 0.0319 & -0.1939 & 0.1127 & $0.0726-$ & -0.0742 & $0.0884-0$ & 0.21541 .0000 \\
\hline
\end{tabular}


The correlation matrix in table 3 Represents the relationship between dependent and independent variables. MGO has positive relationship with DPS, LIQ, TANG and FSIZE, while negative relationship with LEV, SGR and with ROA. As reported by Gujrati (2003) that the variables will have a multicollinearity problem. If the correlation between two independent variables is or greater than 0.80 . The highest value in terms of correlation between independent variables in 0.66873 i.e. between LEV and ROA thus may conclude that our results may have multicollinearity between independent variables but it is less than the threshold limit.

Other value of the correlation with MGO is: the LVE has negative correlation of -0.0578 , DPS has positive correlation of 0.1224 , LIQ has positive correlation of 0.0248 , SGR has negative relationship of -0.0572 , ROA also negative relation with MGO of -0.0218 , TANG has positive relation of 0.0101 and the FSIZE has positive relation of 0.0319 .

\section{GMM estimation method used for Managerial Ownership}

Table 4: System GMM estimation method used for MGO as Dependent and Independent variables

\begin{tabular}{|c|c|c|c|c|}
\hline Dependentvariable & & \multicolumn{3}{|c|}{ Managerial ownership } \\
\hline & Variables name & Label & Coefficient & p-values \\
\hline & Lag dependentvariable & MGO & -.0010848 & 0.479 \\
\hline \multirow{13}{*}{$\begin{array}{c}\text { independent } \\
\text { variables }\end{array}$} & Leverage & LEV & -.003615 & 0.049 \\
\hline & Dividend payout & DPS & .00235 & 0.566 \\
\hline & Liquidity ratio & LIQ & .0249005 & 0.011 \\
\hline & Sale growth rate & SGR & .0011083 & 0.676 \\
\hline & Return on Assets & ROA & .0190831 & 0.055 \\
\hline & Tangible Assets & TAMG & -.0002819 & 0.613 \\
\hline & Firm Size & FSIZE & .0034942 & 0.766 \\
\hline & \multicolumn{3}{|l|}{ Numberofobservations } & 200 \\
\hline & \multicolumn{3}{|l|}{ Numberofgroups } & 40 \\
\hline & \multicolumn{3}{|l|}{ Numberofinstruments } & 23 \\
\hline & \multicolumn{3}{|l|}{ Sargentestpvalue } & 0.8207 \\
\hline & \multicolumn{3}{|l|}{ A-BAR(1) orm1 testp-values } & 0.2261 \\
\hline & \multicolumn{3}{|l|}{ A-BAR(2) orm2testp-values } & 0.2373 \\
\hline
\end{tabular}

$* * *, * *, *$ represents $1 \%, 5 \%, 10 \%$ level of significance, respectively.

Table 4 Shows the regression result for MGO, with DPS, Leverage and with others independent variables. The table 4 Stated values of the result indicates the coefficient and p-values. The result of the Leverage Coefficient shows negative effect on the Managerial ownership, but significant ( $p>0.05$ ) 0.049, it highlights that increase in Leverage cause to decrease the Managerial ownership. Dividend payout (DPS) has positive coefficient value of 0.00235 , but insignificant the result shows that increase in DPS, increased the Managerial ownership. Liquidity has also positive effect on the MGO, the calculated value is 0.0249005 and the p-value is 0.011, a significant effect has the LIQ. Sale Growth, Return on Assets and the Firm Size has positive effect on the Managerial ownership, mostly all of the variables has insignificant association except that the Tangible Assets has negative coefficient value of -.0002819 and the p-value is 0.613 , but insignificant.

\section{GMM estimation method used for Leverage}

Table 5 Highlight the regression result for LEV, the LEV is dependent variable. Results show the relationship with others dependent and independent variables. The result of the MGO Coefficient show negative effect on the Leverage, but significant ( $p>0.05)$ 0.029, it shows that increase in MGO cause to decrease the Leverage. 
Table 5: System GMM estimation method used for LEV as Dependent and Independent variables

\begin{tabular}{|c|c|c|c|c|}
\hline \multirow[t]{2}{*}{ Dependentvariable } & & \multicolumn{3}{|c|}{ Leverage } \\
\hline & Variables name & Label & Coefficient & p-values \\
\hline & Lag dependentvariable & LEV & -.0788669 & 0.000 \\
\hline \multirow{13}{*}{$\begin{array}{l}\text { independent } \\
\text { variables }\end{array}$} & Managerial ownership & MGO & -.2603638 & 0.029 \\
\hline & Dividend payout & DPS & -.0089684 & 0.774 \\
\hline & Liquidity ratio & LIQ & -.3333472 & 0.000 \\
\hline & Sale growth rate & SGR & -.0273149 & 0.000 \\
\hline & Return on Assets & ROA & 4.469802 & 0.000 \\
\hline & Tangible Assets & TAMG & .0027395 & 0.510 \\
\hline & Firm Size & FSIZE & .6628352 & 0.000 \\
\hline & \multicolumn{3}{|l|}{ Numberofobservations } & 200 \\
\hline & \multicolumn{3}{|l|}{ Numberofgroups } & 40 \\
\hline & \multicolumn{3}{|l|}{ Numberofinstruments } & 23 \\
\hline & \multicolumn{3}{|l|}{ Sargentestpvalue } & 0.4592 \\
\hline & \multicolumn{3}{|c|}{ A-BAR(1) orm1testp-values } & 0.0355 \\
\hline & \multicolumn{3}{|c|}{ A-BAR(2) orm2testp-values } & 0.0525 \\
\hline
\end{tabular}

***, **, * represents $1 \%, 5 \%, 10 \%$ level of significance, respectively

Dividend payout (DPS) has negative coefficient value of -0.0089684 , but insignificant. the result shows that increase in DPS, decreased the Leverage. Liquidity has also negative effect on the LEV, the calculated value is -0.3333472 and the p-value is 0.000 , a significant effect has the LIQ. Sale Growth has a negative coefficient and has negative effect on the LEV, -0.0273149 and p-value is 0.000 , significant value. Return on Assets, Tangible Assets and the Firm Size has positive effect on the Leverage, mostly all of the variables have significant association with Leverage.

\section{GMM estimation method used for Leverage}

Table 6: System GMM estimation method used for DPS as Dependent and Independent variables

\begin{tabular}{|c|c|c|c|c|}
\hline \multirow[t]{2}{*}{ Dependentvariable } & \multirow[b]{2}{*}{ Variables name } & \multicolumn{3}{|c|}{ Dividend payout } \\
\hline & & Label & Coefficient & p-values \\
\hline \multirow{14}{*}{$\begin{array}{l}\text { independent } \\
\text { variables }\end{array}$} & Lag dependentvariable & DPS & .2657276 & 0.000 \\
\hline & Managerial Ownership & MGO & .3348595 & 0.197 \\
\hline & Leverage & LEV & -.0585388 & 0.000 \\
\hline & Liquidity ratio & LIQ & -.1901036 & 0.000 \\
\hline & Sale growth rate & SGR & -.0087102 & 0.204 \\
\hline & Return on Assets & ROA & .3182108 & 0.000 \\
\hline & Tangible Assets & TAMG & .0357896 & 0.007 \\
\hline & Firm Size & FSIZE & .1941476 & 0.003 \\
\hline & \multicolumn{3}{|l|}{ Numberofobservations } & 200 \\
\hline & \multicolumn{3}{|l|}{ Numberofgroups } & 40 \\
\hline & \multicolumn{3}{|l|}{ Numberofinstruments } & 23 \\
\hline & \multicolumn{3}{|l|}{ Sargentestpvalue } & 0.0810 \\
\hline & \multicolumn{3}{|c|}{ A-BAR(1) orm1 testp-values } & 0.1647 \\
\hline & \multicolumn{3}{|c|}{ A-BAR(2) orm2testp-values } & 0.9115 \\
\hline
\end{tabular}

Tables 6 show Dividend payout as dependent variable result show the relationship with others dependent and independent variables. The result of the MGO Coefficient show positive effect on the DPS, but insignificant, p-value 0.197., it shows that increase in MGO, decrease the DPS. Leverage has negative 
coefficient value of -0.0585388 , but significant with p-value of 0.000 . The result shows that increase in LEV, decreased the DPS. Liquidity has also negative effect on the DPS, the calculated value is -0.1901036 and the p-value is 0.000 , a significant effect has the LIQ. Sale Growth has a negative coefficient and has negative effect on the DPS, -0.0087102 and p-value is 0.204, insignificant value. Return on Assets, Tangible Assets and the Firm Size has positive effect on the DPS, mostlyall of the variables have significant relationship with DPS.

\section{Conclusion and Implication}

The present work is conducted on the managerial ownership, Leverage and on the dividend payout relations for the period of 2010-2016. The evidence is obtained from the Non-financial firms of the Pakistan stock Exchange. 40 Non-financial firms are selected as sample of the study. The study is based on the secondary data. The data is collected from the company's annual reports, opendoor.com site, and Pakistan stock exchange site and from other business recorder sites. The analysis of the study is completed with the help of Stata software. The study analysis is contained on the descriptive analysis, Correlation matrix and Regression analysis.

The result of descriptive analysis shows number of observations that how much of the observations are included in study. As discussed that the study time period is include on Seven years of time period. The Mean values are derived from the primary data of the study which is collected in the initial stage. The mean value of the study variables shows the average number of the variables numbers. That what is the average number of all of the observation of each variable, for knowing the difference and variance between the Mean and real value (Observation) Std. Dev. Are calculated Slandered deviation is calculated to investigate the variation among the Numbers and Mean. That how much the difference exists between them? The Minimum column in the Descriptive analysis highlights the lowest value of the variables number or it shows the lowest limit. That to how much extent the variable values fall down. And the Maximum show the highest point that to how much extent the data goes up. Skewness shows the important effect of the data. Its shows to which side the data is going. As the standard limit or standard mention by different authors, researchers and investigators that data (Result) is considered to be good when it falls between +1.9 to -1.9.according to this standard the result of the study variables falls in this limit. the kurtosis values for variables shows that all of the calculated values are Lepto-Kurtic, Because mostly variables values are $\beta_{2}>3$. A 2 SLS approach is employed in the study. This approach was also previously used in different literature and research i-e the MansSoderbon (2009) used it in the study of Managerial ownership, Leverage and Dividend payout ratio. The correlation Matrix result indicates that the Managerial ownership has negative relationship with Leverage. Dividend payout has Positive Relationship with Managerial ownership, while Leverage has Negative relationship with Dividend Payout.

Corporate governance creates and establishes rules and regulation, codes creating structures and procedures, also controlling techniques for the management of firms. The main goal of Corporate Governance is to protect the stakeholders benefit. The Problem of Agency theory and for the reduction of cost of organization reduces through the corporate governance, because it is like an instrument for reduction of these problems manager incurred different other type of cost for their own benefit because manager is trying to increase and work for their own benefits instead of working for shareholders and owner benefits. Corporate governance is the system of balancing and checking of different resources. The objective of corporate governance is to monitor and controlling the activities of management in organization. The combination of different directors known as the size of board the size of boards is different from country to country, firm to firm due to its different culture, different type of rules and regulation and also the type of ownership structure. As per the study of Macit (2011), they used the ROA and ROE factors to determine the profitability of firm, and also focused to evaluate specific factors. The conducted on the turkey firms due to different geographical location, some of the work analyzes different issues and problem related to the Profitability of firming system like the estimations from diverse methods. Different investigative research works are conducted on it to know about the important and impact of the 
firm growth. All of the previous studies are trace back to the theory of the firm growth. Almost the entire investigator uses in his/her studies this theory. The study also described the Agency theory, signaling theory and Pecking Order theory. The current work is examined the relationship among the managerial ownership, leverage and dividend payout. Every study has some of the importance, effect and relationship with predictor variable. Numerous of the literatures is conducted on such topic to investigate the association among these variable different approaches are employed to examine the equation structure and variable combination. As the manssoderbom (2009) used 2SLS approach in study to investigate the relationship between managerial ownership, leverage and dividend payout. Takashi Yaman (1995) also used 2SLS in study. Henningsen and D.Hamann (2007) also employed 2SLS approach in study. The present study analysis is consisted on 40 listed companies in Pakistan stock exchange for the period of Seven years. And based on secondary data of 40 companies from different secondary sources the data is collected i-e PSX site, opendoor.com, company annual reports etc. The current study also employed 2SLS approaches for investigation of managerial ownership, Leverage and dividend payout. The result of the regression result indicates that how much level an independent variable has effect on Dependent variable. For finding the result between the Dependent and independent variables the Fixed and Random analysis are implemented. The result from analysis indicates that Managerial ownership and leverage has negative association, managerial ownership and dividend payout has positive relationships, dividend payout and leverage has negative relationship. Leverage has significance effect with managerial ownership while the dividend payout has insignificant effect, dividend payout has insignificant effect on leverage and managerial ownership has significant effect. Dividend payout and managerial ownership has insignificant effect while dividend payout and leverage has significant effect. A fixed effects Model in which the model parameters are fixed or non-random quantities.

In many applications including econometrics and biostatistics a fixed effects model refers to a regression model in which the group means are fixed. Generally, data can be grouped according to several observed factors. In a fixed effects model each group mean is a group-specific fixed quantity. The Random Model is contrast and opposite of Fixed model. While the study conducted analysis also on Hausman test. Hausman test highlight and indicates that which model is good for study between Fixed and Random Effect model.

As the importance of this study is not denied and also not hide from reader. But this study helps more to investor who investing in the Pakistan stock exchange listed companies, it give a secure feel to investor when manager has high ownership in organization. Debt risk is the main issue of every organization, because mostly organizations face trouble due to debt, for controlling financial decision and policies managerial struggling to increase ownership and take control over financial policies with high level ownership of manager lead to low level of leverage and high level of dividend payout. Most of the investor investigating about firm managerial ownership and level of leverage. After that investing in firm it is seemed that small investor ignores that organization that has a high level of leverage or high level of managerial ownership for to reducing the agency conflict. Management using the leverage and dividend as a weapon to reduce such a problem and cost, leverage and dividend policy is an alternative instrument for reduction of agency conflict.

\section{Limitation of Study}

Every study has some kind of limitation, which a researcher faces during the study. Many problems occur in the finalization of work, either the study is Cross sectional in nature or Non-cross-sectional study is it. As like others researches the current study also face different problems like the problem of time. For completion this work the time is short. Because this study is based on cross-sectional that's why the data is taken also from insecure sources as well, which reduce the accuracy of the data. Along with time problem, also problem of data collection, because mostly the companies some time did not publish their annual reports. Due to which face different problem in the data. The financial resources also secure that to get data from the paid sources. 


\section{Recommendation for Future direction}

This study is completed on the Non-financial companies, listed on the Pakistan stock exchange. Evidence is collected from 40 Non-financial Firms and 2SLS approach is used in study. This result is not to be considered as a generalized result for other firms and sectors. Pakistan Stock Exchange is consisting of 575 non-financial listed firms. And this study is just take 40 companies out of 575 . This is a very small portion for huge result. That's why the current result is not considered as the generalized result. 2SLS approach is employed. It is recommended to generalize the result of Managerial ownership, Leverage and Dividend Payout ratio for Non-Financial Firms, suggested to take large sum of population and employed 3SLS approach. Large sum of population gives a generalized result for all Non-financial firms to investigate with large population. For investigating the relation also needed to investigate it with other factors as well.

\section{References}

Ali, K., Akhtar, M. F., \& Ahmed, H. Z. (2011).Bank-specific and macroeconomic indicators of profitability-empirical evidence from the commercial banks of Pakistan. International Journal of Business and Social Science, 2(6), 235-242.

Altunbas, Y., Liu, M. H., Molyneux, P., \& Seth, R. (2000). Efficiency and risk in Japanese banking. Journal of Banking \& Finance, 24(10), 1605-1628.

Athanasoglou, P. P., Brissimis, S. N., \& Delis, M. D. (2008).Bank-specific, industry-specific and macroeconomic determinants of bank profitability. Journal of international financial Markets, Institutions and Money, 18(2), 121-136.

Alpers, D. H., Kalloo, A. N., Kaplowitz, N., Owyang, C., \& Powell, D. W. (2011). Textbook of gastroenterology.John Wiley \& Sons.

Banaga, A., Tomkins, C. R., \& Ray, G. H. (1994). External audit and corporate governance in Islamic banks: A joint practitioner-academic research study. Avebury.

Baskin, J. (1989). An empirical investigation of the pecking order hypothesis. Financial management, 2635.

Bathala, C. T., Moon, K. P., \&Rao, R. P. (1994). Managerial ownership, debt policy, and the impact of institutional holdings: An agency perspective. Financial Management, 38-50.

Berger, A. N., \&Mester, L. J. (1997). Inside the black box: What explains differences in the efficiencies of financial institutions? Journal of banking \& finance, 21(7), 895-947.

Berger, A. N., \&DeYoung, R. (2001). The effects of geographic expansion on bank efficiency. Journal of Financial Services Research, 19(2-3), 163-184.

Berle, A., \& Means, G. (1932).Private property and the modern corporation. New York: Mac-millan.

Boone, A. L., Field, L. C., Karpoff, J. M., \&Raheja, C. G. (2007). The determinants of corporate board size and composition: An empirical analysis. Journal of financial Economics, 85(1), 66-101.

Brealey, R., Leland, H. E., \& Pyle, D. H. (1977).Informational asymmetries, financial structure, and financial intermediation. The journal of Finance, 32(2), 371-387.

Brigham, K. H., De Castro, J. O., \& Shepherd, D. A. (2007). A Person-Organization Fit Model of OwnerManagers' Cognitive Style and Organizational Demands. Entrepreneurship theory and practice, 31(1), $29-51$.

Cadbury, A. (1992). Report of the committee on the financial aspects of corporate governance (Vol. 1). Gee.

Caforio, A. L., Pankuweit, S., Arbustini, E., Basso, C., Gimeno-Blanes, J., Felix, S. B., ...\&Klingel, K. (2013). Current state of knowledge on etiology, diagnosis, management, and therapy of myocarditis: a position statement of the European Society of Cardiology Working Group on Myocardial and Pericardial Diseases. European heart journal, 34(33), 2636-2648.

Cavallo, L., \& Rossi, S. P. (2002). Do environmental variables affect the performance and technical efficiency of the European banking systems? A parametric analysis using the stochastic frontier approach. The European Journal of Finance, 8(1), 123-146.

Chaffey, D. (2001). Internet marketing.Apogeoeditore. 
Chapra, M. U., \& Ahmed, H. (2002).Corporate Governance in IFIs. Islamic Development Bank, Islamic Research and Training Institute, Periodical Document, (6).

Chen, C. R., \& Steiner, T. L. (1999). Managerial ownership and agency conflicts: A nonlinear simultaneous equation analysis of managerial ownership, risk taking, debt policy, and dividend policy. Financial review, 34(1), 119-136

Choudhury, M. A., \&Hoque, M. Z. (2004). An advanced exposition of Islamic economics and finance (Vol. 25).Edwin Mellen Pr.

Clarke, J. (2004). Changing welfare, changing states: New directions in social policy.Sage.

Crutchley, C. E., Jensen, M. R., JaheraJr, J. S., \& Raymond, J. E. (1999). Agency problems and the simultaneity of financial decision making: The role of institutional ownership. International review of financial analysis, 8(2), 177-197.

Davydenko, A. (2010). Determinants of bank profitability in Ukraine. Undergraduate Economic Review, 7(1), 2.

Dietsch, M., \& Lozano-Vivas, A. (2000). How the environment determines banking efficiency: A comparison between French and Spanish industries. Journal of Banking \& Finance, 24(6), 985-1004.

Donaldson, G. (1961). Corporate debt capacity.

Duc, V. H., \&Thuy, P. B. G. (2013). Corporate governance and firm's performance: empirical evidence from Vietnam. Journal of Economic Development, (JED, No. 218), 62-77.

Easterbrook, F. H. (1984). Two agency-cost explanations of dividends. The American Economic Review, 74(4), 650-659.

Eisenbeis, R., Ferrier, G., \& Kwan, S. (1999). The informativeness of stochastic frontier and programming frontier efficiency scores: Cost efficiency and other measures of bank holding company performance.

Gaver, J. J., \&Gaver, K. M. (1993). Additional evidence on the association between the investment opportunity set and corporate financing, dividend, and compensation policies. Journal of Accounting and economics, 16(1-3), 125-160.

Goldstein, I. (n.d.). Capital Structure. Wharton School, University of Pennsylvania, -.

Gordon, M. J. (1963). Optimal investment and financing policy. The Journal of finance, 18(2), 264-272.

Goyal, V. K., \& Park, C. W. (2002).Board leadership structure and CEO turnover. Journal of Corporate Finance, 8(1), 49-66.

Gupta, N. M. (2010, july-december). IMPACT OF DIVIDENDANNOUNCEMENT ON STOCK PRICES. International Journal of Information Technology and Knowledge Management, 2(2), pp. 405-410.

Hamam, A. H. (2007). Systemfit: A package for Estiamting System of Simultaneous equation in R. Journal of Statistical Software, 23(4), 1-40.

Haneef, M. A. (1995). Contemporary Islamic Economic Thought: A Selected Comparative Analysis. Alhoda UK.

BIBLIOGRAPHY Hongmei Gu \& Jiahui Yue. (2011). The Relationship between Bank Efficiency and Stock Returns: Evidence from Chinese Listed Banks. World Journal of Social Sciences, 1(4), 95-106.

Hoque, Z. (2004). A contingency model of the association between strategy, environmental uncertainty and performance measurement: impact on organizational performance. International Business Review, 13(4), 485-502.

Iqbal, Z., \&Mirakhor, A. (2004). Stakeholders model of governance in Islamic economic system.

Jensen, G. R., Solberg, D. P., \& Zorn, T. S. (1992). Simultaneous determination of insider ownership, debt, and dividend policies. Journal of Financial and Quantitative analysis, 27(2), 247-263.

Jensen, M. C. (1993). The modern industrial revolution, exit, and the failure of internal control systems. the Journal of Finance, 48(3), 831-880.

Jensen, M. C., \&Meckling, W. H. (1976). Theory of the firm: Managerial behavior, agency costs and ownership structure. Journal of financial economics, 3(4), 305-360

Jensen, M., \&Zajac, E. J. (2004). Corporate elites and corporate strategy: How demographic preferences and structural position shape the scope of the firm. Strategic Management Journal, 25(6), 507-524.

Kim, S. Y. (2015, November,December). Article The Dynamic Relationship between Growth and Profitability under Long-Term Recession: The Case of Korean Construction Companies. (A. E. Sousa, Ed.) Sustainability, 7, 15982-15998. 
Kidd, J., Richter, F. J., \& Li, X. (2003). Learning and trust in supply chain management. Management Decision, 41(7), 603-612.

Klock, M. S., Mansi, S. A., \& Maxwell, W. F. (2005). Does corporate governance matter to bondholders?. Journal of Financial and Quantitative Analysis, 40(4), 693-719.

Kwan, S., \&Eisenbeis, R. A. (1997).Bank risk, capitalization, and operating efficiency. Journal of financial services research, 12(2-3), 117-131.

Leland, H. E., \& Pyle, D. H. (1977).Information asymmetries, financial structure, and financial intermediation.The Journal of Finance, 32(2), 371-387. HYPERLINK "http://dx.doi.org/10.2307/2326770" http://dx.doi.org/10.2307/2326770

Lintner, J. (1956). Distribution of incomes of corporations among dividends, retained earnings, and taxes. The American Economic Review, 46(2), 97-113.

Lipton, M., \&Lorsch, J. W. (1992).A modest proposal for improved corporate governance. The business lawyer, 59-77.

Lipunga, A. M. (2014). Determinants of Profitability of Listed Commercial Banks in Developing Countries: Evidence from Malawi. Research Journal of Finance and Accounting, 5(6), 41-49.

Majid, M. Z. A., \&Sufian, F. (2006). Consolidation and competition in emerging market: an empirical test for Malaysian banking industry. Economic Change and Restructuring, 39(1-2), 105-124.

Mallin, C., Mullineux, A., \&Wihlborg, C. (2005). The financial sector and corporate governance: the UK case. Corporate Governance: An International Review, 13(4), 532-541.

Mester, L. J. (1997). Measuring efficiency at US banks: Accounting for heterogeneity is important. European Journal of Operational Research, 98(2), 230-242.

Miller, M. H., \& Modigliani, F. (1961).Dividend policy, growth, and the valuation of shares. the Journal of Business, 34(4), 411-433.

Milliken, F. J., \& Martins, L. L. (1996).Searching for common threads: Understanding the multiple effects of diversity in organizational groups. Academy of management review, 21(2), 402-433.

Mohammad Hashemijoo, A. M. (2014). The Impact of Dividend Policy on Share Price Volatility in the Malaysian Stock Marke. Journal of Business Studies Quarterly , 4(1), pp.111-129.

Moussa, F. B., \&Chichti, J. (2013). A survey on the relationship between ownership structure, debt policy and dividend policy in Tunisian stock exchange: Three stage least square simultaneous model approach. International Journal of Accounting and Economics Studies, 2(1), 1-21

Myers, S. C., \&Majluf, N. S. (1984). Corporate financing and investment decisions when firms have information that investors do not have. Journal of financial economics, 13(2), 187-221.

Myers, S. C. (2001). Capital structure. Journal of Economic perspectives, 15(2), 81-102.

Negash, S. (2004).Business intelligence. The communications of the Association for Information Systems, 13(1), 54.

Nielsen, J. (2000). Why you only need to test with 5 users.

Pasiouras, F., \&Kosmidou, K. (2007).Factors influencing the profitability of domestic and foreign commercial banks in the European Union. Research in International Business and Finance, 21(2), 222-237.

Rajan, R. G., \&Zingales, L. (1995). What do we know about capital structure? Some evidence from international data. The journal of Finance, 50(5), 1421-1460.

Rahaman, M. M., \&Akhter, S. (2016). Bank-specific factors influencing profitability of Islamic banks in Bangladesh. Journal of Business and Technology (Dhaka), 10(1), 21-36.

Ross, S. A. (1977). The determination of financial structure: the incentive-signalling approach. The bell journal of economics, 23-40.

Rozeff, M. S. (1982). Growth, beta and agency costs as determinants of dividend payout ratios. Journal of financial Research, 5(3), 249-259.

Shleifer, A., \&Vishny, R. W. (1997).The limits of arbitrage. The Journal of Finance, 52(1), 35-55.

Shyam-Sunder, L., \& Myers, S. C. (1999).Testing static tradeoff against pecking order models of capital structure1. Journal of financial economics, 51(2), 219-244.

Smith Jr, C. W., \& Watts, R. L. (1992). The investment opportunity set and corporate financing, dividend, and compensation policies. Journal of financial Economics, 32(3), 263-292. 
Snowden, D. J., \& Boone, M. E. (2007). A leader's framework for decision making. Harvard business review, 85(11), 68 .

Stulz, R. (1990). Managerial discretion and optimal financing policies. Journal of financial Economics, 26(1), 3-27.

Stenbaek-Nielsen, H. C., Moudry, D. R., Wescott, E. M., Sentman, D. D., \& Sao Sabbas, F. T. (2000). Sprites and possible mesospheric effects. Geophysical Research Letters, 27(23), 3829-3832.

Nguyen, D. H.-Y. (2014, April). Managerial ownership, Leverage and Dividend Policies: Empirical Evidence from Vietnam's Listed firms. International Journal of Economics and Finance, 6(5), 274284.

Soderbom, M. (2009). Applied Econometric: Lectur 2: instrumental Variables, 2SLS and GMM. Applied Econometric, 1-68.

Topuz, B., \&Macit, M. (2011). Solid phase extraction and preconcentration of $\mathrm{Cu}$ (II), Pb (II), and Ni (II) in environmental samples on chemically modified Amberlite XAD-4 with a proper Schiff base. Environmental monitoring and assessment, 173(1-4), 709-722.

Tortosa-Ausina, E. (2003). Nontraditional activities and bank efficiency revisited: a distributional analysis for Spanish financial institutions. Journal of Economics and Business, 55(4), 371-395.

Tuigong Wilson Kibet, J. A. (2016). Effects of Dividend Policy on Share Price of Firms Listed at the Nairobi Securities Exchange, Kenya . Research Journal of Finance and Accounting , 7(8), 220-230. Retrieved from www.iiste.org

Vargas, C. M. (2000). Community development and micro-enterprises: Fostering sustainable development. Sustainable Development, 8(1), 11.

Vardar, G. (2013). Efficiency and Stock Performance of Banks in Transition Countries: Is There A Relationship? International Journal of Economics and Financial Issues, 3(2), 355-369. Retrieved from www.econjournals.com.

Vishwa Nath Maruya, R. S. (2015, March 10). (Correlation analysis between the corporate governance and financial performance of banking sectors using parameter estimation. American Journal of Theoritical and Applied Statistics, iv(2-1), 27-32. doi:10.11648/j.ajtas.s.2015040201.14

Yamano, T. (1995). LInstrumental Variables Estimation. Lecture Notes on Advanced Econometrics, 1-34. 